\title{
Inference of Multiple Earthquake-Cycle Relaxation Timescales from Irregular Geodetic Sampling of Interseismic Deformation
}

\section{Citation}

Meade, Brendan J., Yann Klinger, and Eric A. Hetland. 2013. “Inference of Multiple Earthquake-Cycle Relaxation Timescales from Irregular Geodetic Sampling of Interseismic Deformation." Bulletin of the Seismological Society of America 103 (5) (October 1): 2824-2835. doi:10.1785/0120130006. http://dx.doi.org/10.1785/0120130006.

\section{Published Version}

doi:10.1785/0120130006

\section{Permanent link}

http://nrs.harvard.edu/urn-3:HUL.InstRepos:12497388

\section{Terms of Use}

This article was downloaded from Harvard University's DASH repository, and is made available under the terms and conditions applicable to Other Posted Material, as set forth at http:// nrs.harvard.edu/urn-3:HUL.InstRepos:dash.current.terms-of-use\#LAA

\section{Share Your Story}

The Harvard community has made this article openly available.

Please share how this access benefits you. Submit a story.

Accessibility 


\title{
Inference of Multiple Earthquake-Cycle Relaxation Timescales from Irregular Geodetic Sampling of Interseismic Deformation
}

\author{
by Brendan J. Meade, Yann Klinger, and Eric A. Hetland
}

\begin{abstract}
Characterizing surface deformation throughout a full earthquake cycle is a challenge due to the lack of high-resolution geodetic observations of duration comparable to that of characteristic earthquake recurrence intervals (250-10,000 years). Here we approach this problem by comparing long-term geologic slip rates with geodetically derived fault slip rates by sampling only a short fraction $(0.001 \%-0.1 \%)$ of a complete earthquake cycle along 15 continental strike-slip faults. Geodetic observations provide snapshots of surface deformation from different times through the earthquake cycle. The timing of the last earthquake on many of these faults is poorly known, and may vary greatly from fault to fault. Assuming that the underlying mechanics of the seismic cycle are similar for all faults, geodetic observations from different faults may be interpreted as samples over a significantly larger fraction of the earthquake cycle than could be obtained from the geodetic record along any one fault alone. As an ensemble, we find that geologically and geodetically inferred slip rates agree well with a linear relation of $0.94 \pm 0.09$. To simultaneously explain both the ensemble agreement between geologic and geodetic slip-rate estimates with observations of rapid postseismic deformation, we consider the predictions from simple two-layer earthquake-cycle models with both Maxwell and Burgers viscoelastic rheologies. We find that a two-layer Burgers model, with two relaxation timescales, is consistent with observations of deformation throughout the earthquake cycle, whereas the widely used two-layer Maxwell model with a single relaxation timescale, is not, suggesting that the earthquake cycle is effectively characterized by a largely stressrecoverable rapid postseismic stage and a much more slowly varying interseismic stage.
\end{abstract}

\section{Introduction}

Geodetic measurements of surface deformation provide high-resolution observations of interseismic strain accumulation, as well as both co- and postseismic fault slips. However, characterizing the behavior of a complete earthquake cycle is not straightforward due to the long recurrence intervals associated with large earthquakes. Observational timescales for contemporary geodetic observations (Global Positioning System and Interferometric Synthetic Aperture Radar) typically range from 1 to 20 years, encompassing only a small fraction of the earthquake cycle in the latest Holocene. As a result, inferences of earthquake-cycle behavior and viscosity structure of the lower crust and uppermost mantle have been limited and contradictory. For example, in the context of earthquake-cycle models assuming a single relaxation timescale, analysis of postseismic deformation suggested upper mantle effective viscosities of, or less than, $10^{18} \mathrm{~Pa}$ s (e.g., Pollitz et al., 2001) whereas late in the earthquake-cycle deformation has been interpreted as consistent with viscosities of a subseismogenic layer exceeding $10^{19} \mathrm{Pas}$ (e.g., Hilley et al., 2005; Meade and Hager, 2005). More recently, the analysis of postseismic deformation signals has led to the suggestion that single relaxation timescale models may not be sufficient to describe behavior within the postseismic regime alone (e.g., Pollitz et al., 2001; Pollitz, 2003, 2005; Freed and Bürgmann, 2004; Ryder et al., 2007; Hearn et al., 2009).

Comparisons between geologic and geodetic fault slip-rate estimates may provide insight into the mechanics of the earthquake cycle. Idealized earthquake-cycle models fall into two general classes: (1) quasistatic classical elastic half-space ( $\mathrm{CEH}$ ) models, and (2) dynamic earthquake-cycle (DEC) models. In the former, deformation between earthquakes is assumed to be time invariant (Savage and Burford, 1973; Savage, 1983), whereas in the latter, deformation rates vary continuously throughout the earthquake cycle due to the relaxation of coseismic stresses (e.g., Nur and Mavko, 1974; Savage and Prescott, 1978; Cohen, 1982; Li and Rice, 1987; Savage, 2000; Johnson and Segall, 2004; Hetland and Hager, 2005). CEH models are a frequently used method 


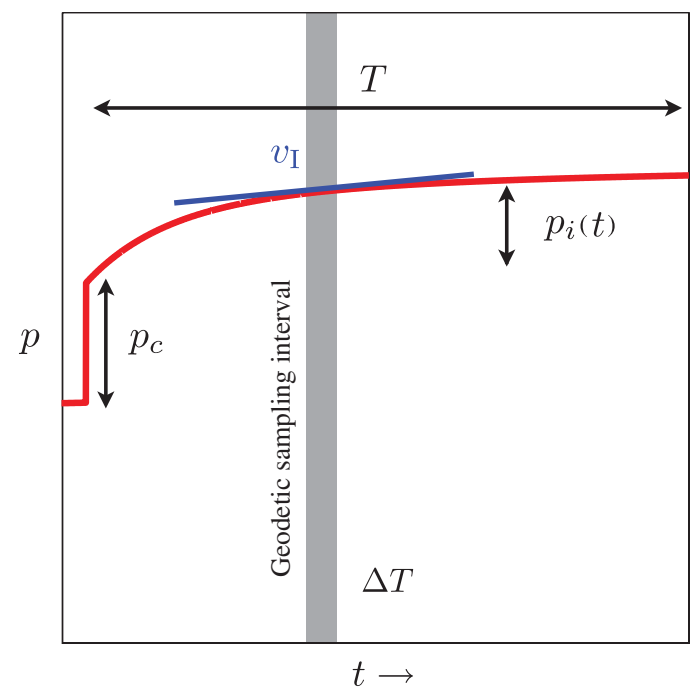

Figure 1. Schematic diagram showing a geodetic sampling interval in relation to the earthquake cycle. Earthquake recurrence intervals $(T)$ typically range from 100 to 10,000 years whereas the duration geodetic observations, $\Delta T$ (vertical gray shading), used to infer fault slip rates, is typically decadal in length, sampling only a small fraction of the earthquake cycle. A linear fit to the geodetic position time series $p_{i}(t)$ (red line) throughout $T$ gives the nominal interseismic velocity, $v_{\text {I }}$ (blue line). Estimates of $v_{\text {I }}$ may vary throughout the earthquake cycle because of the nonlinear variation in surface deformation throughout the interseismic period.

for interpreting geodetic velocity gradients near faults and estimating fault slip rates and locking depths, mainly due to their simplicity and low computational cost. Additionally, and more importantly, CEH models are often argued to adequately represent interseismic deformation, as geodetically determined velocities often appear to be steady in time over the period of observation that typically ranges from 5 to 20 years, only a small fraction of the full interseismic period, which may range from hundreds to several thousands of years (Fig. 1).

However, steady-state CEH models are inconsistent with observations of spatially broad $(>100 \mathrm{~km})$, time-variable, postseismic deformation following large earthquakes (e.g., Nur and Mavko, 1974; Hetland and Hager, 2003; Pollitz, 2003; Freed and Bürgmann, 2004; Freed et al., 2006; Ryder et al., 2007). Models for time-dependent earthquake-cycle deformation have generally focused on either the diffuse deformation of a linear viscoelastic subseismogenic layer (e.g., Thatcher, 1983; Savage, 1990; Dixon et al., 2002, 2003; Ergintav et al., 2002; Segall, 2002; Hilley et al., 2005, Motagh et al., 2007) or localized shear on a down-dip extension of the coseismic fault zone (e.g., Marone et al., 1991; Bürgmann et al., 2002), whereas recently more postseismic models have incorporated both (e.g., Freed et al., 2006; Johnson et al., 2009). Both deformation mechanism models have been extended to predict time-variable surface deformation throughout the entire earthquake cycle under the assumption of periodic earthquake occurrence (Savage and Prescott, 1978; Cohen, 1982; Johnson and Segall, 2004; Hetland and Hager,
2005) and to clustered and nonperiodic earthquake occurrence (Meade and Hager, 2004; Hetland and Hager, 2006). However, the most common tools for interpreting nominally interseismic geodetic velocity fields are, by far, still CEH models. Whereas CEH models may provide an adequate representation of a surface velocity field, neglecting dynamic earthquake-cycle processes may bias estimates of fault slip rates and locking depths (e.g., Hetland and Hager, 2006), leading to potentially inaccurate estimates of the parameters critical for characterizing tectonic motions and earthquake recurrence intervals.

The common usage of CEH models provides an opportunity to estimate the systematic biases introduced through the neglect of DEC time variability. Because of the fact that the same simple CEH model has been used for a majority of geodetic slip-rate estimates, we can constrain systematic biases by studying how idealized dynamic earthquake-cycle models map into fault slip-rate estimates when CEH models are used to interpret the predictions from these models. For example: What would be the apparent distribution of fault slip rates if a CEH model was used to interpret the velocities predicted by a time-dependent viscous shear zone model? This test can be carried out to determine the bias introduced by the CEH model interpretation of any DEC model. The fundamental biases introduced from a CEH model due to viscoelastic relaxation effects have been previously detailed (Hetland and Hager, 2006). Here we investigate if such biases can be identified observationally by applying DEC models to previously published geodetic slip-rate estimates along continental strike-slip faults derived from geodetic data and 2D CEH models.

Geodetic measurements, and thus, CEH slip-rate estimates are derived from a small interval of time through a longer earthquake cycle. We assume that these slip-rate estimates may be inaccurate due to the fact that potential DEC effects have been neglected, and we assume that HoloceneQuaternary slip-rate estimates accurately represent the longterm fault slip rate. Hence, we can compare the geodetically constrained CEH estimates to reference geologic slip-rate estimates to determine: (1) How well do geologically and geodetically inferred fault slip rates agree as an ensemble? and (2) What dynamic earthquake-cycle models are these data consistent with?

\section{Geologic and Geodetic Slip-Rate Estimates on Continental Strike-Slip Faults}

Geologic and geodetic slip-rate estimates are available for many faults globally but more rarely available on nearly collocated fault segments. We have compiled a database of approximately collocated geologic and geodetic slip-rate estimates from 15 major continental strike-slip faults (Alpine, Altyn Tagh, Dead Sea, Elsinore, Fairweather, Garlock, Karakoram, San Andreas fault [SAF]-Mojave, North Anatolian, Owens Valley, Philippine, SAF-Carrizo, SAF-Indio, San Jacinto, and Haiyuan) derived from a search of the published 
(a)

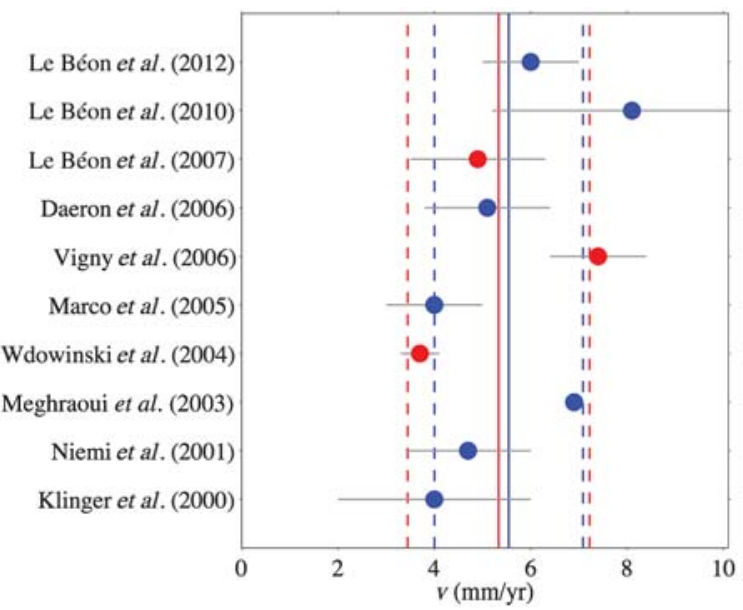

(c)

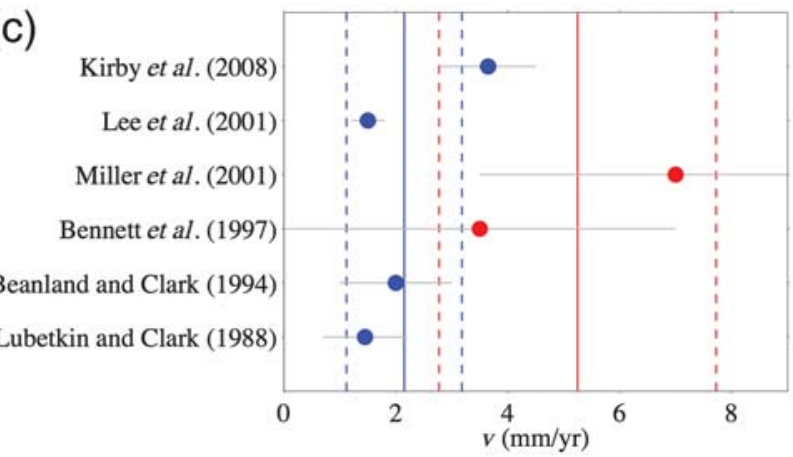

(b)

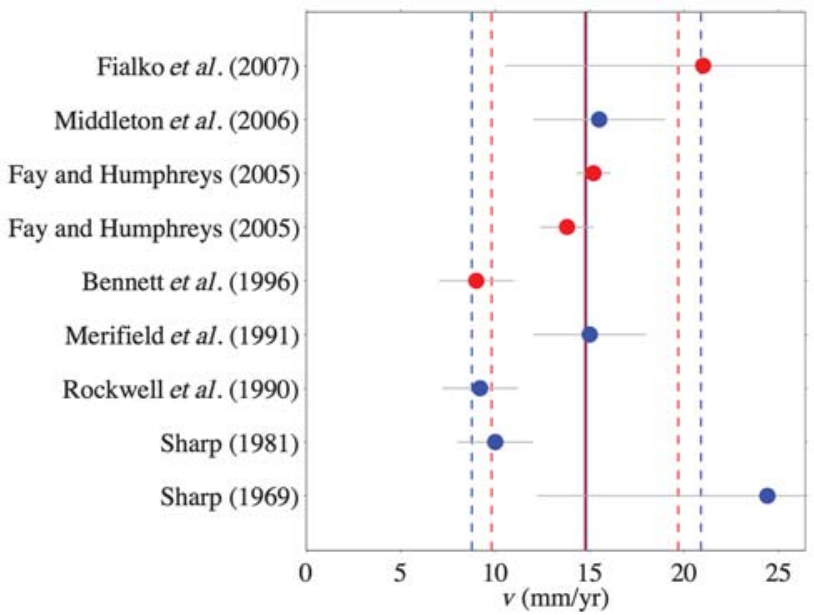

(d)

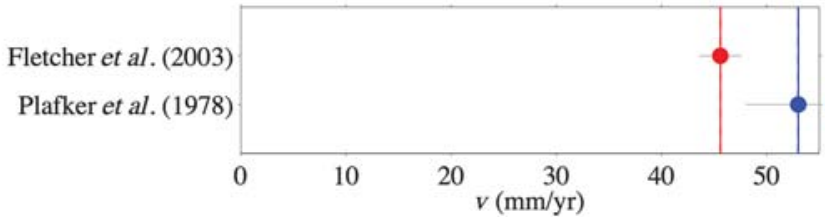

Figure 2 Examples of geologic and geodetic fault slip-rate estimates for the (a) Dead Sea, (b) San Jacinto, (c) Owens Valley, and (d) Fairweather faults. Each of these is arranged chronologically with the earliest study results at the bottom. Red and blue dots represent geodetic and geologic estimates, respectively. Gray lines are the uncertainties reported in each study. Solid red and blue vertical lines are the average geodetic and geologic estimates, respectively, with the vertical dashed lines showing $67 \%$ confidence intervals.

literature (Figs. 2, 3, Table 1). Here we restrict our study to strike-slip faults to enable the comparison with idealized models, whereas previous geologic/geodetic slip-rate comparisons have included a wider array of faulting types (Thatcher, 2009). Geologic rates are restricted to estimates averaged over the most recent time period available, ranging from Holocene to mid-Pleistocene and are determined based on the direct measurement of geomorphologic markers. These estimates represent averages over multiple earthquake cycles, effectively smoothing out variations due to clustered seismicity. Notably, geologic slip-rate estimates at specific locations may not be consistent with one another because of different methodological approaches to offset reconstructions (e.g., Mériaux et al., 2004; Cowgill, 2007). All geodetic slip-rate estimates considered here are inferences from simple 2D quasistatic interseismic deformation models (Savage and Burford, 1973). Although limiting this study to the analysis of 2D CEH models limit the number of geodetic slip-rate estimates (neglecting constraints from viscoelastic and block models that assume a slip budget constraint), it does ensure that the same modeling technique has been applied in all cases.

A simple way to characterize the relationship between these paired slip-rate estimates is to solve for the best-fitting slope between geologic and geodetic slip-rate estimates. Assuming that both $\mathrm{CEH}$ and geologic estimates pass through the origin at zero slip rate, we find a geologic-geodetic scaling line with a best-fit slope $m=0.94 \pm 0.09$ at $67 \%$ confidence using a weighted least-squares fit (Fig. 3). We systematically estimate how the best-fitting slope varies as a function of selecting subsets of the more complete slip-rate estimates catalog. The empirical bootstrap distribution gives a geologic-geodetic scaling line with $m=0.94 \pm 0.13$ at $67 \%$ confidence (Fig. 4) and is not statistically distinguishable from the weighted least-squares estimate at the $95 \%$ confidence level according to the $t$-test statistic.

\section{Geodetic Slip-Rate Estimates as Samples of Earthquake-Cycle Deformation}

Because high-resolution geodetic observations of nominally interseismic deformation only span the past 5-20 years, we do not have a complete record of surface deformation throughout an entire $T=250-10,000$ year long earthquake cycle, for which $T$ is the mean recurrence interval for large earthquakes. Because of slow variations in surface velocities, position time series may often appear to vary linearly due to 


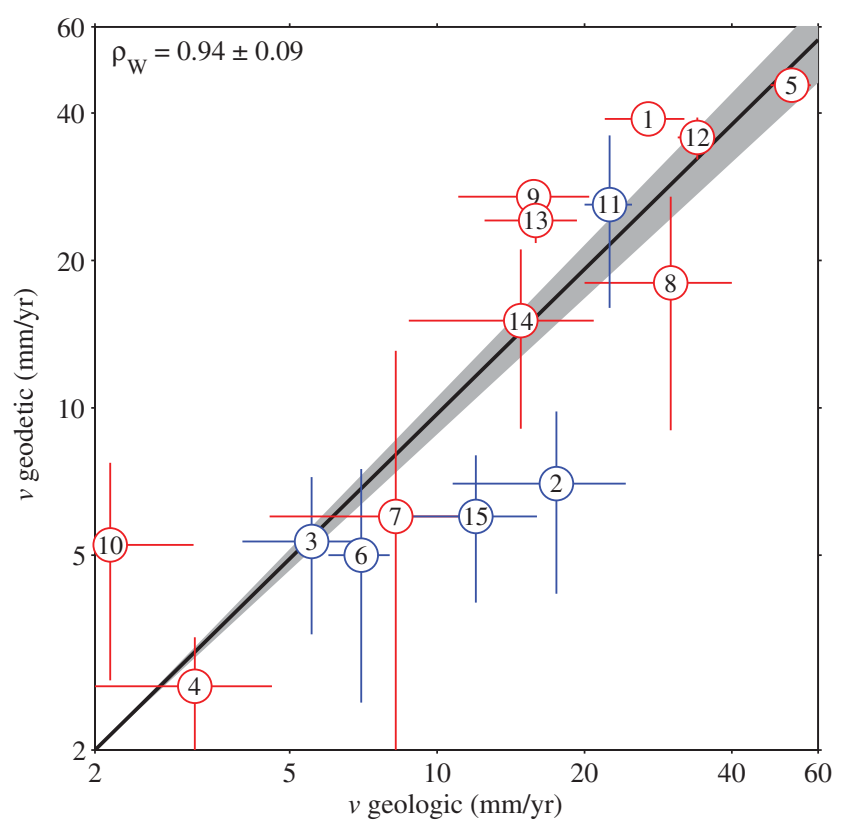

Figure 3. Geological and geodetic fault slip-rate comparison. Geographic distribution of the 15 strike-slip faults considered in this study: (1) Alpine, (2) Altyn Tagh, (3) Dead Sea, (4) Elsinore, (5) Fairweather, (6) Garlock, (7) Karakoram, (8) SAF-Mojave, (9) North Anatolian, (10) Owens Valley, (11) Philippine, (12) SAF-Carrizo, (13) SAF-Indio, (14) San Jacinto, and (15) Haiyuan (Sharp, 1967, 1981; Savage and Burford, 1973; Plafker et al., 1978; Sieh and Jahns, 1984; Lubetkin and Clark, 1988; Rockwell et al., 1990; Barrier et al., 1991; Lisowski et al., 1991; Merifield et al., 1991; McGill and Sieh, 1993; Beanland and Clark, 1994; Duquesnoy et al., 1994; Petersen and Wesnousky, 1994; Bennett et al., 1996, 1997; Armijo et al., 1999; Beavan et al., 1999; Lasserre et al., 1999; Bendick et al., 2000; Klinger et al., 2000; Reilinger et al., 2000; Argus and Gordon, 2001; Lee et al., 2001; Miller et al., 2001; Niemi et al., 2001; Norris and Cooper, 2001; Banerjee and Bürgmann, 2002; Brown et al., 2002; Hubert-Ferrari et al., 2002; Fletcher and Freymueller, 2003; Meghraoui et al., 2003; Lacassin et al., 2004; Mériaux et al., 2004, 2005, 2012; Polonia et al., 2004; Wdowinski et al., 2004; Wright et al., 2004; Chevalier et al., 2005; Fay and Humphreys, 2005; Marco et al., 2005; Matmon et al., 2005; Fialko, 2006; Middleton, 2006; Schmalzle et al., 2006; van der Woerd et al., 2006; Vigny et al., 2006; Daeron et al., 2007; Kirby et al., 2007; Kozaci et al., 2007; Cavalie et al., 2008; Le Béon et al., 2008, 2010, 2012; Cowgill et al., 2009). The solid dark line, the dashed black line, and shaded gray region show the weighted linear fits with $67 \%$ confidence intervals with slopes $0.94 \pm 0.09$.

the fact that the rate of velocity change associated with timedependent earthquake-cycle processes is below the signalto-noise ratio (Fig. 1). However, by combining geodetic slip-rate estimates from different faults, each potentially at a different stage of the seismic cycle, we may assemble a more complete sampling of deformation throughout an earthquake cycle. This approach allows us to develop a statistical sample of the earthquake cycle, assuming that the physical processes governing behavior throughout the earthquake cycle are the same for all of the considered faults. The interseismic geodetic data for the faults studied in this paper may effectively provide 15 different sampling times throughout the earthquake cycle. A particular challenge associated with this sort of approach is to identify where in the earthquake cycle each particular fault might occur. This is difficult due to the fact that the time since the last earthquake on the particular segment of the fault where geodetic are available is, in general, not known, nor is it known when the next earthquake will occur. The Carrizo segment of the SAF is an example of a locale where there are nearly collocated constraints on geologic fault slip rate (Sieh and Jahns, 1984), geodetic slip rate (e.g., Schmalzle et al., 2006), the date of the last large earthquake (1857), and the associated coseismic slip (Liu et al., 2004). Here we take the approach that in the absence of clear information about recurrence times and the date of the last rupture in the vicinity of geodetic observations, the interseismic geodetic observations considered here are essentially sampling a random time $(t)$ from somewhere within an individual earthquake cycle. However, for some of the faults considered, such as the Carrizo segment of the SAF described above, we know that a large earthquake has not occurred in the years immediately preceding the period of geodetic observations; therefore we are unlikely to observe the immediate postseismic regime. As a simple candidate for the duration of the geodetic observation window, we assume that these data sample the majority of the earthquake cycle with the exception of the years immediately following a large earthquake, $t / T \leq 0.02$, where the direct observation of time-dependent surface velocities would likely be the sensible applications of $\mathrm{CEH}$ models to infer fault slip rates. Other possibilities may certainly be defensible but we choose this particular window because it is conservative in the sense of being as long as possible and not biased toward the middle of the earthquake cycle as might be a smaller window. In the following sections, comparing with DEC models we perform tests with multiple realizations of possible geodetic sampling times.

\section{Constraining Time-Dependent Earthquake-Cycle Models}

\section{Relating Time-Dependent Models to Observations}

Dynamic earthquake-cycle models are based on the assumption that stresses generated by the coseismic rupture in the elastic upper crust are either diffused throughout an underlying viscoelastic layer (Fig. 5) or are relieved on a localized lower crustal fault or shear zone. Savage and Prescott (1978) solved for the time-dependent surface velocities under the assumption that the viscoelastic layer is governed by a Maxwell rheology and that earthquake occurrence is periodic. Hetland and Hager (2005) extended this model to include nonperiodic earthquake sequences and generalized linear viscoelastic rheologies, including the transient Burgers rheology. Johnson and Segall (2004) also extended the Savage and Prescott (1978) model to include the localized creep on a linear viscous shear zone within the upper elastic layer. 
Table 1

Compilation of Geologic and Geodetic Fault Slip-Rate Estimates

\begin{tabular}{|c|c|c|}
\hline Fault & Slip Rate $(\mathrm{mm} / \mathrm{yr})$ & Reference \\
\hline Alpine & $38.9 \pm 1.5$ & Beavan et al. (1999) \\
\hline Alpine & $27.0 \pm 5.0$ & Norris and Cooper (2001) \\
\hline AltynTagh & $9.0 \pm 5.0$ & Bendick et al. (2000) \\
\hline AltynTagh & $5.0 \pm 5.0$ & Wright et al. (2004) \\
\hline AltynTagh & $26.9 \pm 6.9$ & Mériaux et al. (2004) \\
\hline AltynTagh & $17.8 \pm 3.6$ & Mériaux et al. (2005) \\
\hline AltynTagh & $13.9 \pm 1.1$ & Mériaux et al. (2012) \\
\hline AltynTagh & $11.5 \pm 2.5$ & Cowgill et al. (2009) \\
\hline Dead Sea & $4.0 \pm 2.0$ & Klinger et al. (2000) \\
\hline Dead Sea & $4.7 \pm 1.3$ & Niemi et al. (2001) \\
\hline Dead Sea & $6.9 \pm 0.1$ & Meghraoui et al. (2003) \\
\hline Dead Sea & $3.7 \pm 0.4$ & Wdowinski et al. (2004) \\
\hline Dead Sea & $4.0 \pm 1.0$ & Marco et al. (2005) \\
\hline Dead Sea & $7.4 \pm 1.0$ & Vigny et al. (2006) \\
\hline Dead Sea & $5.1 \pm 1.3$ & Daeron et al. (2007) \\
\hline Dead Sea & $4.9 \pm 1.4$ & Le Béon et al. (2008) \\
\hline Dead Sea & $8.1 \pm 2.9$ & Le Béon et al. (2010) \\
\hline Dead Sea & $6.0 \pm 1.0$ & Le Béon et al. (2012) \\
\hline Elsinore & $3.2 \pm 1.4$ & Petersen and Wesnousky (1994) \\
\hline Elsinore & $2.7 \pm 0.7$ & Fay and Humphreys (2005) \\
\hline Fairweather & $53.0 \pm 5.0$ & Plafker et al. (1978) \\
\hline Fairweather & $45.6 \pm 2.0$ & Fletcher and Freymueller (2003) \\
\hline Garlock & $7.0 \pm 1.0$ & McGill and Sieh (1993) \\
\hline Garlock & $5.0 \pm 2.5$ & Miller et al. (2001) \\
\hline Karakoram & $11.0 \pm 4.0$ & Banerjee and Bürgmann (2002) \\
\hline Karakoram & $4.0 \pm 1.0$ & Brown et al. (2002) \\
\hline Karakoram & $1.0 \pm 6.0$ & Wright et al. (2004) \\
\hline Karakoram & $10.0 \pm 0.3$ & Lacassin et al. (2004) \\
\hline Karakoram & $10.7 \pm 0.7$ & Chevalier et al. (2005) \\
\hline SAF (Mojave) & $18.0 \pm 9.0$ & Lisowski et al. (1991) \\
\hline SAF (Mojave) & $30.0 \pm 10.0$ & Matmon et al. (2005) \\
\hline North Anatolian & $14.0 \pm 7.0$ & Armijo et al. (1999) \\
\hline North Anatolian & $27.0 \pm 1.0$ & Reilinger et al. (2000) \\
\hline North Anatolian & $18.5 \pm 3.5$ & Hubert-Ferrari et al. (2002) \\
\hline North Anatolian & $10.0 \pm 5.0$ & Polonia et al. (2004) \\
\hline North Anatolian & $20.5 \pm 5.5$ & Kozaci et al. (2007) \\
\hline Owens Valley & $1.4 \pm 0.8$ & Lubetkin and Clark (1988) \\
\hline Owens Valley & $2.0 \pm 1.0$ & Beanland and Clark (1994) \\
\hline Owens Valley & $3.5 \pm 3.5$ & Bennett et al. (1997) \\
\hline Owens Valley & $7.0 \pm 3.5$ & Miller et al. (2001) \\
\hline Owens Valley & $1.5 \pm 0.3$ & Lee et al. (2001) \\
\hline Owens Valley & $3.6 \pm 0.8$ & Kirby et al. (2007) \\
\hline Philippines & $22.5 \pm 2.5$ & Barrier et al. (1991) \\
\hline Philippines & $26.0 \pm 10.0$ & Duquesnoy et al. (1994) \\
\hline SAF (Carrizo) & $32.0 \pm 5.0$ & Savage and Burford (1973) \\
\hline SAF (Carrizo) & $34.0 \pm 3.0$ & Sieh and Jahns (1984) \\
\hline SAF (Carrizo) & $39.0 \pm 19.5$ & Argus and Gordon (2001) \\
\hline SAF (Carrizo) & $36.0 \pm 2.0$ & Schmalze et al. (2006) \\
\hline SAF (Carrizo) & $26.0 \pm 2.0$ & Bennett et al. (1996) \\
\hline SAF (Indio) & $21.4 \pm 0.5$ & Fay and Humphreys (2005) \\
\hline SAF (Indio) & $15.9 \pm 3.4$ & van der Woerd et al. (2006) \\
\hline SAF (Indio) & $25.0 \pm 12.5$ & Fialko (2006) \\
\hline San Jacinto & $24.4 \pm 12.2$ & Sharp (1967) \\
\hline San Jacinto & $10.0 \pm 2.0$ & Sharp (1981) \\
\hline San Jacinto & $9.2 \pm 2.0$ & Rockwell et al. (1990) \\
\hline San Jacinto & $15.0 \pm 3.0$ & Merifield et al. (1991) \\
\hline San Jacinto & $9.0 \pm 2.0$ & Bennett et al. (1996) \\
\hline San Jacinto & $13.8 \pm 1.4$ & Fay and Humphreys (2005) \\
\hline San Jacinto & $15.5 \pm 3.5$ & Middleton (2006) \\
\hline San Jacinto & $21.0 \pm 10.5$ & Fialko (2006) \\
\hline
\end{tabular}

Table 1 (Continued)

\begin{tabular}{rcl}
\hline Fault & Slip Rate $(\mathrm{mm} / \mathrm{yr})$ & \multicolumn{1}{c}{ Reference } \\
\hline Haiyuan & $12.0 \pm 4.0$ & Lasserre et al. $(1999)$ \\
Haiyuan & $6.0 \pm 2.0$ & Cavalie et al. (2008)
\end{tabular}

Faults included are the Alpine, AltynTagh, Dead Sea, Elsinore, Fairweather, Garlock, Karakoram, SAF-Mojave, North Anatolian, Owens Valley, Philippine, SAF-Carrizo, SAF-Indio, San Jacinto, and Haiyuan faults. Uncertainties are those reported in the original publications with exception of cases where no uncertainties were reported, where uncertainties are considered to be half the magnitude of the slip-rate estimate.

Here we consider two different earthquake-cycle models (Fig. 5). Geometrically, both models consist of two layers: (1) an elastic upper crust (schizosphere) and (2) a viscoelastic substrate (plastosphere) that serves as a proxy for the lower crust and mantle. The entire thickness of the crust is ruptured along an infinitely long, vertical strike-slip fault generating the stresses that drive time-dependent earthquake-cycle deformation. We consider two idealized rheological models as governing the relaxation of the mantle, (1) Maxwell viscoelasticity (Savage and Prescott, 1978; Savage, 2000), (2) Burgers viscoelasticity (Hetland and Hager, 2005), and consider the case where there is only a single set of material properties in the lower layer so that there is only one relaxation time for the Maxwell rheology and two for the Burgers rheology (Fig. 5). Both of the considered rheologies can produce a period of rapid postseismic deformation during which nearfault (within 4-5 fault locking depths) surface velocities are accelerated relative to the steady CEH model expectation (Fig. 6a,b). However, relatively fast near-surface velocities

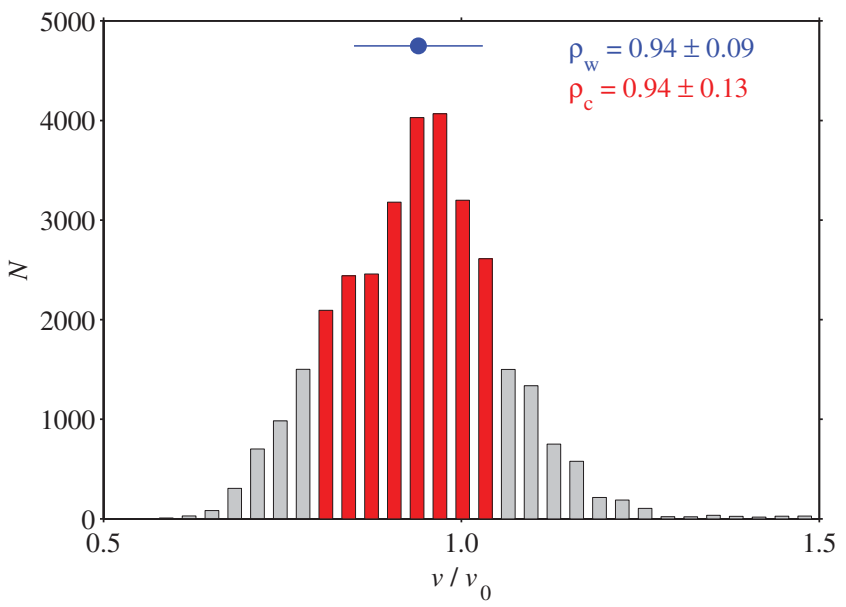

Figure 4. Frequency distribution of slip-rate regression estimates from all possible combinations of geologic/geodetic fault slip-rate pairs. Red shaded portion of the frequency distribution shows the $67 \%$ confidence interval that is twice than that from the linear regression of all pairs. The mean values for the two regression estimates (weighted average of all data: $\rho_{\mathrm{w}}=0.94 \pm 0.09$, combinations of all possible data subsets, $\rho_{\mathrm{c}}=0.94 \pm 0.13$ ) agree, whereas the $67 \%$ confidence interval is approximately $50 \%$ larger when all possible subsets are considered. 
(a)

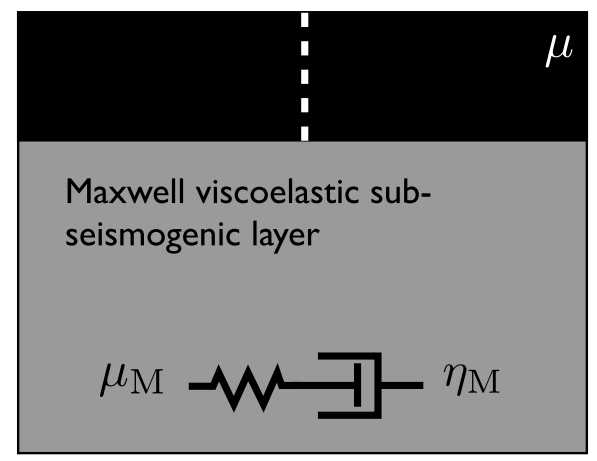

(b)

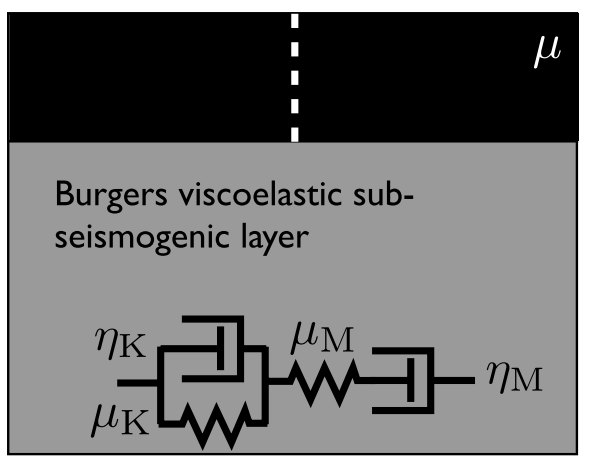

Figure 5. Schematic representations of model geometries and rheologies. The elastic seismogenic upper crust (black) is cut by a throughgoing vertical strike-slip fault (white dashed line). In both (a) and (b) the entire subseismogenic layer (plastosphere) is governed by uniform linear Maxwell and Burgers viscoelastic rheologies, respectively. In all models the shear modulus is taken as 30 GPa. Throughout this paper we assume $\mu=\mu_{\mathrm{M}}=\mu_{\mathrm{K}}$. The viscosities of the Maxwell and Kelvin components of the Burgers rheological model are given by $\eta_{\mathrm{M}}$ and $\eta_{\mathrm{K}}$, respectively.
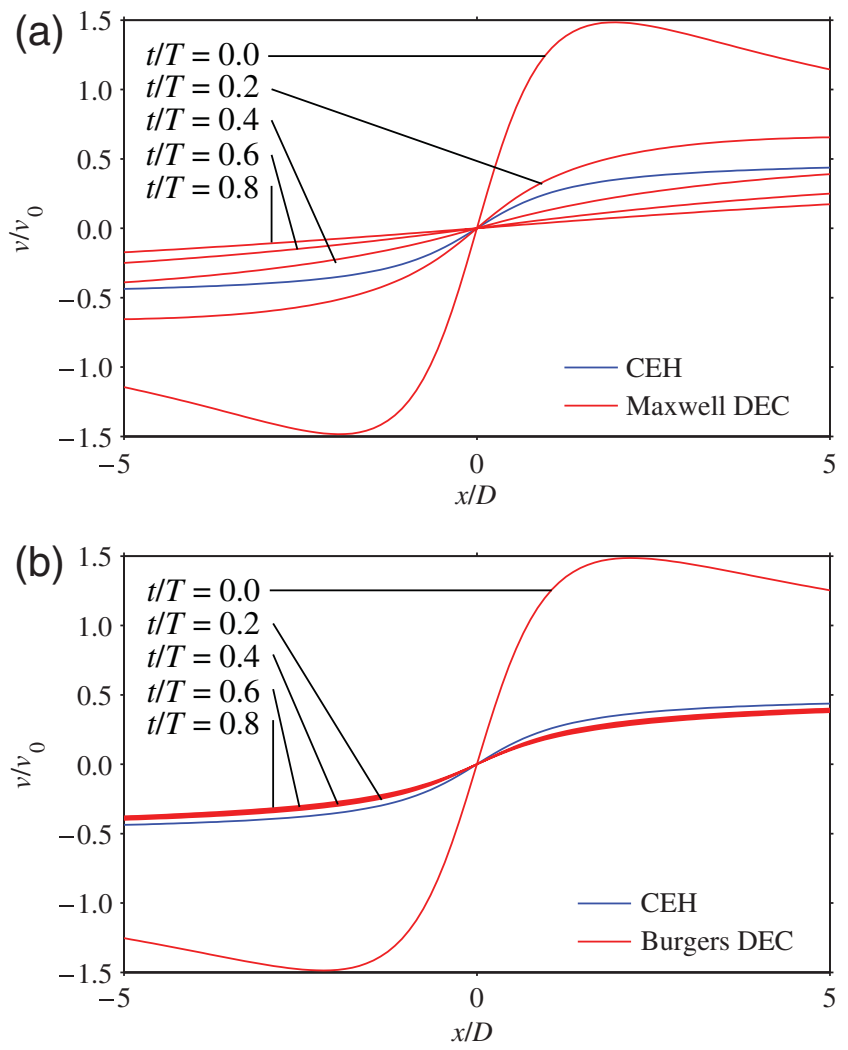

Figure 6. Fault-parallel velocities through periodic earthquake cycles with (a) Maxwell and (b) Burgers rheology substrates. Both cases have identical thickness of the seismogenic layer $(D)$ with the fault at the origin, and red lines showing velocities at five intervals equally spaced in time. The Maxwell rheology model is characterized by $\tau_{0}=T \mu / 2 \eta=5$ and the Burgers rheology has material constants $\mu_{\mathrm{M}}=\mu_{\mathrm{K}}$ and $\eta_{\mathrm{M}} / \eta_{\mathrm{K}}=37$, with $\eta_{\mathrm{M}}$ assumed to be the same as in the Maxwell model. Both models share approximately the same maximum magnitude of postseismic deformation. Solid blue lines show fault-parallel velocities for the quasi-static CEH model (see also fig. 19 in Hetland and Hager, 2005).

during the postseismic regime must be balanced by velocities slower than CEH expectations at other times in the earthquake cycle so that the total displacement at any point is equal to the long-term fault slip rate when integrated over the complete co- and interseismic stages of the earthquake cycle.

For linear viscoelastic models, we can predict timedependent surface velocities throughout the earthquake cycle (e.g., Savage, 2000; Hetland and Hager, 2005). These synthetic surface velocities can then be fit using a CEH to estimate fault slip rates in the same way as has been done with real world geodetic observations used in the geologicgeodetic slip rate detailed above (Fig. 7). In this way, we can compare the expectation in CEH estimates of fault slip rates from dynamic earthquake-cycle models with CEH inferences from real geodetic observations. The comparison is not made on a fault-by-fault basis, but rather we seek to understand which of these models can reproduce the ensemble statistics of the 15 faults considered here. To do this we sample synthetic velocities predicted at 15 random intervals from $t / T=$ $0.02-1.00$ representing a potentially different temporal sampling time for each fault. Velocities are calculated on 10 synthetic observation coordinates randomly distributed within three locking depths of the fault trace. A mean CEH slip-rate estimate from an underlying DEC model can then be calculated and directly comparable to the observed geologic-geodetic slip-rate scaling (Fig. 8). To understand the sensitivity of the estimated average CEH slip rate to the 15 randomly selected observation intervals and the locations of the synthetic observation coordinates, we simulate 1000 realizations for each dynamic earthquake-cycle model considered.

In the CEH model the steady, time-independent, surface velocities are given by $v=v_{0} / \pi \tan ^{-1}(x / D)$, where $v_{0}$ is the long-term, or prescribed, fault slip rate, $x$ is the distance of the observations from the fault trace, and $D$ is the locking depth of the fault (Savage and Burford, 1973). As described above, we randomly sample $x$ and solve for $v_{0}$, which is a linear problem if $D$ is assumed to be known. However, it is not always the case in the real world that we know a priori and so it may also be treated as a free parameter. For this reason we carry out simulations, some assuming that the locking depth is known, and others where it is considered 


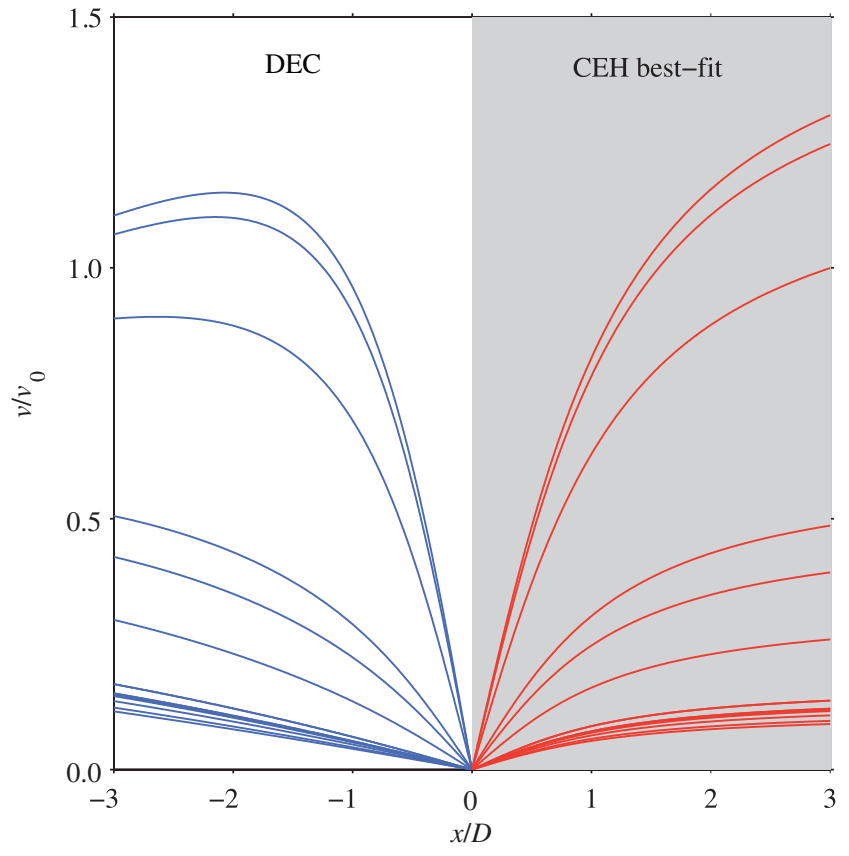

Figure 7. Comparison between velocity profiles from a DEC (blue lines, left side) model and corresponding best-fit profiles assuming a CEH (red lines, right side) space model. The CEH lines are meant to show how the CEH model may often approximate a DEC model in the near field (within three locking depths of the fault). Throughout we assume that geodetically constrained fault slip rates are estimated by this mapping from DEC to best-fitting CEH model. The disagreement between the two models is greatest at the beginning of each earthquake cycle.

a free parameter that is simultaneously estimated with fault slip rate using a simple grid-search approach.

\section{Maxwell Rheology}

The total variability throughout the earthquake cycle and the magnitude of postseismic deformation in two-layer Maxwell rheology models are controlled by the parameter $\tau_{0}=T \mu / 2 \eta=T / 2 \tau_{\mathrm{M}}$, in which $T$ is the duration of the earthquake cycle, $\mu$ is the shear modulus of both the seismogenic and subseismogenic layers, $\eta$ is the viscosity in the subseismogenic layer, and $\tau_{\mathrm{M}}$ is the Maxwell time (Savage and Prescott, 1978). We consider $\tau_{0}$ ranging from 0.01 to 30 (Fig. 9a,b). At low $\tau_{0}$, there is little variability in surface velocities through the earthquake cycle. For typical earthquake recurrence intervals of 100-1000 years, low values of $\tau_{0}$ result from relatively high Maxwell viscosities, $\eta_{\mathrm{M}}>10^{19}$ Pas. However, low $\tau_{0}$ cases do not predict rapid postseismic transients. Larger values of $\tau_{0}>10$ do predict rapid postseismic transient deformation but also feature negligible near-fault velocity gradients late in the earthquake cycle (Fig. 5a). Because of the fact that fault-parallel velocities decay below the CEH model expectation approximately $40 \%$ of the way through the earthquake cycle, a majority of CEH slip-rate estimates are less than the assumed reference slip rate (Figs. 6, 7). For this classic two-layer Maxwell

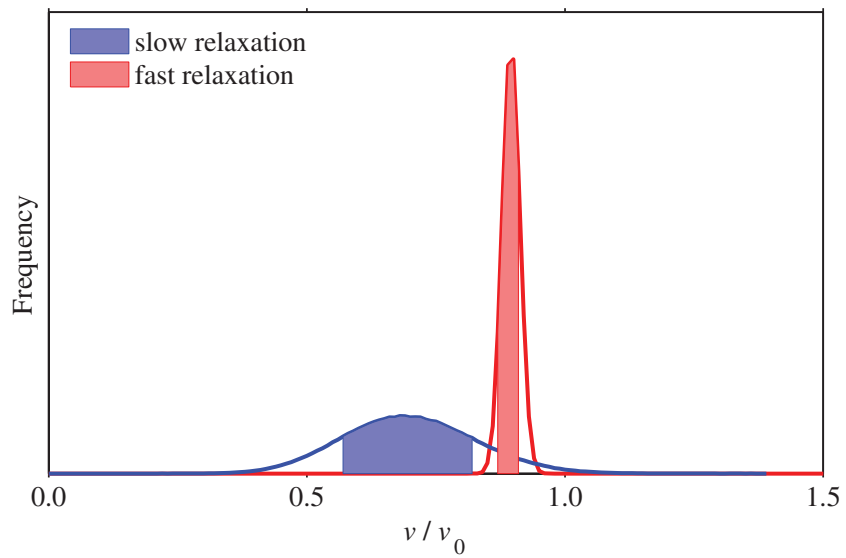

Figure 8. Frequency distribution of fault slip rates recovered using a quasi-static elastic half-space model from surface velocity profiles produced by time-dependent viscoelastic earthquake-cycle models. The red and blue distributions show the mean recovered estimate velocity (averaged over 15 faults identical to the geologic-geodetic comparison in Fig. 2). Two Maxwell viscoelastic earthquake cycle models (red, low $\tau_{0}$; blue, high $\tau_{0}$ ) were simulated 1000 times with random temporal sampling throughout the earthquake cycle. The frequency distribution of the estimated slip correlation is narrower for the low-variability case (red) than it is for the high-variability case (blue). The dispersion in each case can be represented as $67 \%$ probability intervals as shown. This representation of dispersion is used in Figure 9.

model, we find no value of $\tau_{0}$ that can simultaneously explain both the limited variability in nominally interseismic deformation and rapid postseismic deformation (Fig. 9a,b).

\section{Burgers Rheology}

The Burgers rheology combines Maxwell and KelvinVoigt elements in series in a system with two viscosities (Fig. 5b). We test models where the shear moduli are equal $\left(\mu_{\mathrm{M}}=\mu_{\mathrm{K}}\right)$ and vary the ratio of the Maxwell to Kelvin viscosities, $\eta_{\mathrm{M}} / \eta_{\mathrm{K}}$ from 0.01 to 30 (Fig. 9c,d). It is important to note that the transient component of the Burgers viscoelastic model (i.e., represented by the Kelvin-Voigt element) is recoverable (e.g., Findley et al., 1976), and this recoverability has implications for the deformation throughout the intersesimic period (Hetland and Hager, 2005). At $\eta_{\mathrm{M}} / \eta_{\mathrm{K}}$ ratios $<5$, Burgers rheology models predict negligible postseismic relaxation and variation in surface deformation through the earthquake cycle similar to Maxwell models at low $\tau_{0}<1$. Increasing the $\eta_{\mathrm{M}} / \eta_{\mathrm{K}}$ ratio increases the magnitude of velocities in the immediate postseismic regime. Also similar to Maxwell rheology models, near-fault velocity gradients are less than the CEH expectation for the majority of the earthquake cycle, suggesting the CEH slip-rate estimates should be systematically lower than the reference slip rate. For models with $\eta_{\mathrm{M}} / \eta_{\mathrm{K}}>10$, CEH slip-rate inferences overestimate the reference slip rate by approximately $15 \%$ through the majority of the earthquake cycle (Figs. 6, 7). However, in contrast to Maxwell rheology models with rapid postseismic deformation ( $>3$ times long-term slip rates), deformation in 

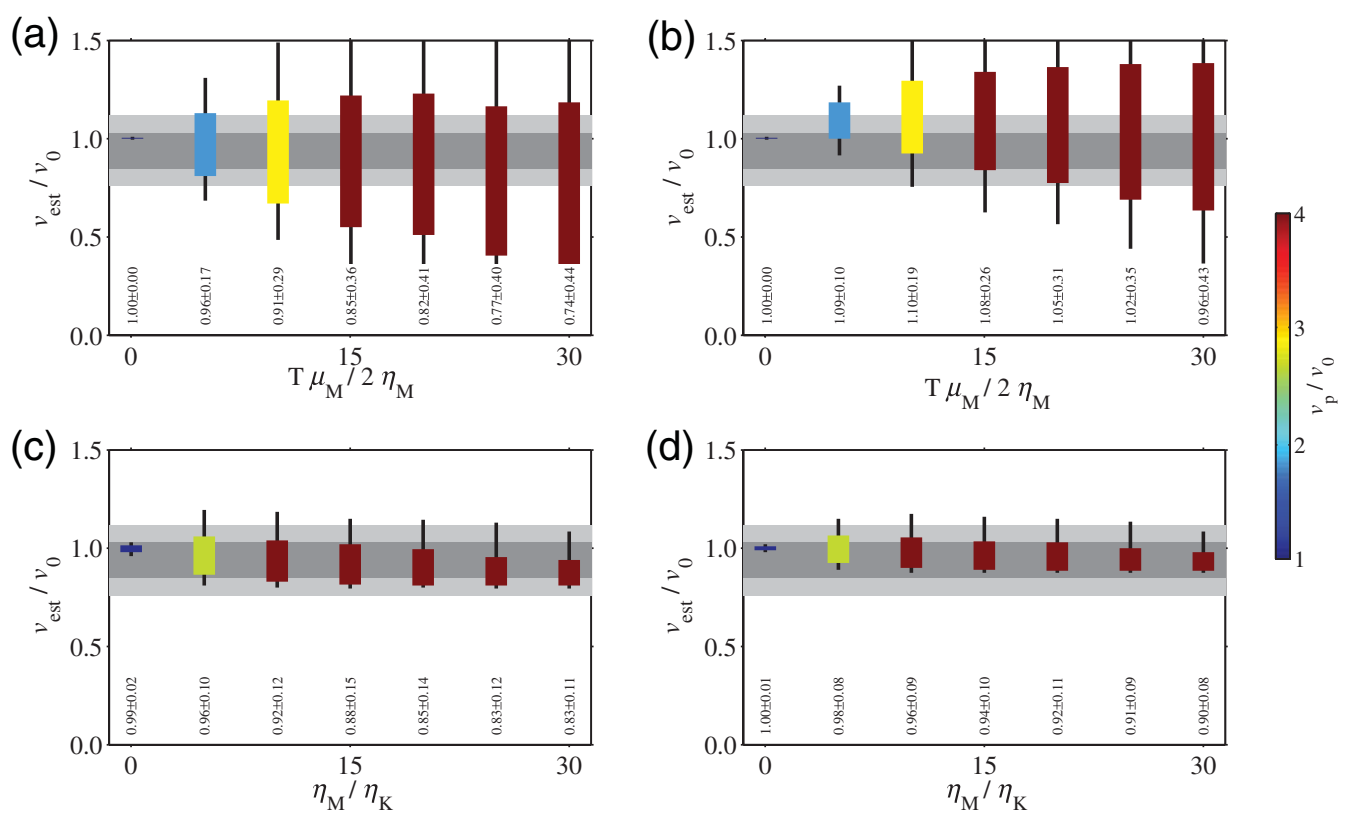

Figure 9. Mean and dispersion of quasi-static elastic half-space slip-rate estimates approximating predictions from Maxwell and Burgers viscoelastic models. The solid gray and light gray horizontal lines show the $67 \%$ and $95 \%$ confidence intervals from the geologic and geodetic slip-rate estimates shown in Figures 2 and 4. Colored lines show the 67\% probability intervals obtained from 1000 simulations and black lines show the $95 \%$ probability interval. Vertical numbers give the value of the best-fit slope describing the relationship between prescribed slip rates and those recovered from a CEH model interpretation of DEC model velocities. The four cases shown are (a) Maxwell viscoelastic with slip-rate inferences from fixed locking depth CEH model, (b) Maxwell viscoelastic with slip-rate inferences from variable locking depth CEH model, (c) Burgers viscoelastic with slip-rate inferences from fixed locking depth CEH model, and (d) Burgers viscoelastic with slip-rate inferences from variable locking depth CEH model. For the Burgers viscoelastic models, $\eta_{\mathrm{M}} / \eta_{\mathrm{K}}$ varies while $\mu_{\mathrm{M}} / \mu_{\mathrm{K}}=1$. Warmer colors indicate a large magnitude postseismic response. CEH estimates of slip rates from a Maxwell viscoelastic DEC models, with fixed locking depth, show a low mean and high dispersion compared to geologic and geodetic slip-rate estimates. CEH estimates of slip rates from Burgers viscoelastic DEC models with $\eta_{\mathrm{M}} / \eta_{\mathrm{K}}>7.5$ best match the mean and dispersion constrained by geologic/geodetic scaling line and are consistent with observations of rapid postseismic deformation.

Burgers rheology models remains localized near the fault trace throughout the majority of the earthquake cycle (Hetland and Hager, 2005). Cases in which $\eta_{\mathrm{M}} / \eta_{\mathrm{K}}>20$ predict both near-field postseismic velocities exceeding the geologic slip rate by a factor of three or more and continued near-fault strain late in the earthquake cycle (Figs. 6b, 9c,d). Following the immediate postseismic regime, the variability in predicted surface deformation rates throughout the earthquake cycle is qualitatively consistent with general agreement between geologically and geodetically constrained earthquakecycle models.

\section{Discussion}

In the context of the idealized two-layer earthquake-cycle models discussed here, the Burgers rheology is plausibly consistent with both the observation of rapid postseismic deformation and the ensemble agreement between geologically and geodetically inferred slip-rate estimates, whereas the Maxwell rheology model is not. Although this model has significant explanatory power and is simple, it does not serve as a unique solution to the problem. For example, a Maxwell model characterized by $\tau_{0}<1$ can explain the agreement between geologically and geodetically inferred slip rates
(Fig. 9a), although it does not simultaneously predict rapid postseismic deformation ubiquitously observed following large continental earthquakes (e.g., Hetland and Hager, 2005; Hearn et al., 2009). If a Maxwell model was supplemented with a deep frictional or viscous shear zone extending downward from the seismogenic fault in the upper crust, rapid postseismic deformation could be described by transient localized creep on that deep fault/shear zone (Hearn et al., 2002; Johnson and Segall, 2004; Montési, 2004; Hetland et al., 2010). Similarly, a thin layer, representing a Maxwell viscoelastic lower crust, sandwiched between an elastic upper crust and upper mantle (i.e., an upper mantle with relaxation timescale much larger than the earthquake recurrence time) also produces multiple relaxation times (Segall, 2010) and can simultaneously describe both rapid postseismic deformation and the late in the earthquake-cycle strain rate localization (Robinson and Meade, 2011). Transient phases of postseismic relaxation predicted by both the deep shear-zone and layered Maxwell models are nonrecoverable, and in terms of the stress budget throughout the full interseismic period are distinctly different from Burgers viscoelastic rheology (Hetland and Hager, 2005). In this paper, the velocities in the Burgers DEC models predicted during most of the interseismic period do not appreciably vary and are close to the $\mathrm{CEH}$ velocities largely because 
the transient viscoelastic rheology we use is stress recoverable. The interpretation of $\eta_{\mathrm{K}}$ in the Burgers DEC models is unclear, and its relation to rock deformation experiments is less clear as most of those experiments use more complicated transient rheologies (e.g., Chopra, 1997; Gribb and Cooper, 1998; Jackson et al., 2002). We find that the relatively simple Burgers viscoelastic model is capable to phenomenologically explain observed interseismic deformation.

In each of these models the nominally interseismic phase of the earthquake cycle is characterized by slowly varying velocities that may be reasonably well represented with CEH models. Although this result may appear convenient from the perspective of simplicity, it raises a particular challenge in terms of using present-day geodetic data to infer how far along in an earthquake cycle is a particular fault. This seems to be the case even here where we have limited our analysis to the idealized case of periodically forced earthquakes. With the Burgers rheology, models that best explain the observed variations in fault-parallel velocities vary slowly throughout the latter half of the earthquake cycle. For a fault such as the San Andreas with a recurrence time as short as 250 years (Fumal et al., 1993) and a Holocene slip rate of $34 \mathrm{~mm} / \mathrm{yr}$ (Sieh and Jahns, 1984), this implies a deceleration in fault-parallel velocities $<0.1 \mathrm{~mm} / \mathrm{yr}^{2}$ as the time to the next earthquake decreases. The geodetic accuracy required to measure such rate changes may be just within reach of contemporary continuous monitoring techniques (Davis et al., 2003).

Our characterization of earthquake-cycle behavior described has been developed on the basis of three critical assumptions: (1) random temporal sampling, (2) robustness of geologically estimated slip rates, and (3) models of 2D infinitely long faults. It is possible that we could move from an assumption of stochastic sampling to having the data available to do similar calculations deterministically. For those calculations, one would need geodetic data collocated along a fault segment for which we also know the date of the last rupture and mean recurrence time. Currently, it seems as if the Carrizo segment of the SAF and the Lebanon segment of the Dead Sea fault may meet all three of these criteria. However, for the Carrizo segment of the SAF, substantial debate has recently emerged in terms of the recurrence intervals of large events prior to the 1857 earthquake (Liu-Zeng et al., 2006; Akçiz et al., 2010). Furthermore we have assumed that the average of the geologically estimated fault slip rates on the selected continental strike-slip faults is the representative of long-term averages (hundreds of earthquake cycles). The assumption that the average of the previously published sliprate estimates is a meaningful value that may be an oversimplification of the variation in slip-rate estimates along strike as well as methodological differences in the interpretations of geologic observables (e.g., Cowgill, 2007). Again, as with timing since the last earthquake, ideal experiments would be those where all data were compiled on exactly the same fault segment. The introduction of finite-length faults to the two-layer Maxwell model may improve the ability to fit geo- detic data (e.g., Hearn et al., 2013) as compared with the infinitely long 2D fault models considered here. However, relaxation times are the same in both $2 \mathrm{D}$ and $3 \mathrm{D}$ cases, and thus so are the velocity decay rates throughout the earthquake cycle. As a result, the finite-fault single relaxation time (Maxwell rheology) two-layer model should be testable on the basis of the prediction of the more rapid, and thus more easily observable, decay rates.

\section{Conclusion}

One of the major difficulties in characterizing the earthquake cycle is the deficit of continuous observations throughout a complete earthquake cycle. With the exception of moderate earthquakes with very short recurrence intervals, such as those at Parkfield, this observational limit will not change without decades of additional seismic and geodetic observations. Hence the task of characterizing variations in fault behavior throughout the earthquake cycle along any single fault segment capable of generating large earthquakes is not currently accessible. Here we have proposed a different approach to this problem by not studying an individual fault but rather integrating observations from 15 continental strike-slip faults, assuming that the same earthquake-cycle model may be applied to all.

We have shown that two of the most widely observed behaviors throughout the earthquake cycle (rapid postseismic deformation and localized preseismic strain rates) as well as the ensemble agreement between geologically and geodetically inferred fault slip rates may be explained by simple models with at least two relaxation timescales (with one transient and recoverable and one steady and nonrecoverable) but not models assuming a single relaxation timescale (Savage and Prescott, 1978). Similar inferences have also recently been made on the basis of decadal observations of postseismic data alone (e.g., Ryder et al., 2007; Hearn et al., 2009). These results suggest that, in contrast to the classical single relaxation time model, variations in surface velocities throughout the earthquake cycle may be subtle and challenging to identify in the presence of multiple faults and observational noise. Thus inferring the time since the last earthquake, or the time till the next, from geodetic observations may require greater accuracy and precision than anticipated.

\section{Data and Resources}

All data used in this paper came from published sources listed in the References.

\section{Acknowledgments}

We thank Associate Editor Roland Bürgmann, reviewer Kaj Johnson, and one anonymous reviewer for thoughtful comments. Support to B. J. M. was provided by Harvard University. Support to E. A. H. was provided by NSF Grant EAR-1045372. Y. K. was partly supported by NSF Grant EAR-0440145 and the Department of Earth \& Planetary Sciences at Harvard University. 


\section{References}

Akçiz, S., L. Grant Ludwig, J. R. Arrowsmith, and O. Zielke (2010). Century-long average time intervals between earthquake ruptures of the San Andreas fault in the Carrizo Plain, California, Geology 38, 787-790.

Argus, D. F., and R. G. Gordon (2001). Present tectonic motion across the Coast Ranges and San Andreas fault system in central California, Geol. Soc. Am. Bull. 113, 1580-1592.

Armijo, R., B. Meyer, A. Hubert, and A. Barka (1999). Westward propagation of the North Anatolian fault into the northern Aegean: Timing and kinematics, Geology 27, 267-270.

Banerjee, P., and R. Bürgmann (2002). Convergence across the northwest Himalaya from GPS measurements, Geophys. Res. Lett. 29, 1652.

Barrier, E., P. Huchon, and M. Aurelio (1991). Philippine fault: A key for Philippine kinematics, Geology 19, 32-35.

Beanland, S., and M. M. Clark (1994). The Owens Valley fault zone, eastern California, and surface faulting associated with the 1872 earthquake, U.S. Geol. Surv. Bull. 1982, 1-29.

Beavan, J., M. Moore, C. Pearson, M. Henderson, B. Parsons, S. Bourne, P. England, D. Walcott, G. Blick, and D. Darby (1999). Crustal deformation during 1994-1998 due to oblique continental collision in the central Southern Alps, New Zealand, and implications for seismic potential of the Alpine fault, J. Geophys. Res. 104, 25,233-25,255.

Bendick, R., R. Bilham, J. Freymueller, K. Larson, and G. H. Yin (2000). Geodetic evidence for a low slip rate in the Altyn Tagh fault system, Nature 404, 69-72.

Bennett, R. A., W. Rodi, and R. E. Reilinger (1996). Global Positioning System constraints on fault slip rates in southern California and northern Baja, Mexico, J. Geophys. Res. 101, 21,943-21,960.

Bennett, R. A., B. P. Wernicke, J. L. Davis, P. Elosegui, J. K. Snow, M. J. Abolins, M. A. House, G. L. Stirewalt, and D. A. Ferrill (1997). Global Positioning System constraints on fault slip rates in the Death Valley region, California and Nevada, Geophys. Res. Lett. 24, 3073-3076.

Brown, E. T., R. Bendick, D. L. Bourles, V. Gaur, P. Molnar, G. M. Raisbeck, and F. Yiou (2002). Slip rates of the Karakorum fault, Ladakh, India, determined using cosmic ray exposure dating of debris flows and moraines, J. Geophys. Res. 107, B2192, ESE-7.

Bürgmann, R., S. Ergintav, P. Segall, E. H. Hearn, S. McClusky, R. E. Reilinger, H. Woith, and J. Zschau (2002). Time-space variable afterslip on and deep below the Izmit earthquake rupture, Bull. Seismol. Soc. Am. 92, 126-137.

Cavalie, O., C. Lasserre, M. P. Doin, G. Peltzer, J. Sun, X. Xu, and Z. K. Shen (2008). Measurement of interseismic strain across the Haiyuan fault (Gansu, China), by InSAR, Earth Planet. Sci. Lett. 275, 246-257.

Chevalier, M. L., F. J. Ryerson, P. Tapponnier, R. C. Finkel, J. van der Woerd, H. B. Li, and Q. Liu (2005). Slip-rate measurements on the Karakorum Fault may imply secular variations in fault motion, Science 307, 411-414.

Chopra, P. N. (1997). High-temperature transient creep in olivine rocks, Tectonophysics 279, 93-111.

Cohen, S. C. (1982). A multilayer model of time-dependent deformation following an earthquake on a strike-slip fault, J. Geophys. Res. 87, $5409-5421$.

Cowgill, E. (2007). Impact of riser reconstructions on estimation of secular variation in rates of strike-slip faulting: Revisiting the Cherchen River site along the Altyn Tagh Fault, NW China, Earth Planet. Sci. Lett. 254, 239-255.

Cowgill, E., R. D. Gold, C. Xuanhua, W. Xiao-Feng, J. R. Arrowsmith, and J. Southon (2009). Low Quaternary slip rate reconciles geodetic and geologic rates along the Altyn Tagh fault, northwestern Tibet, Geology 37, 647-650.

Daeron, M., Y. Klinger, P. Tapponnier, A. Elias, E. Jacques, and A. Sursock (2007). 12,000-year-long record of 10 to 13 paleoearthquakes on the Yammouneh fault, Levant fault system, Lebanon, Bull. Seismol. Soc. Am. 97, 749-771.
Davis, J. L., R. A. Bennett, and B. P. Wernicke (2003). Assessment of GPS velocity accuracy for the Basin and Range Geodetic Network (BARGEN), Geophys. Res. Lett. 30, 1411.

Dixon, T., J. Decaix, F. Farina, K. Furlong, R. Malservisi, R. Bennett, F. Suarez-Vidal, J. Fletcher, and J. Lee (2002). Seismic cycle and rheological effects on estimation of present-day slip rates for the Agua Blanca and San Miguel-Vallecitos faults, northern Baja California, Mexico, J. Geophys. Res. 107, 2226.

Dixon, T. H., E. Norabuena, and L. Hotaling (2003). Paleoseismology and Global Positioning System: Earthquake-cycle effects and geodetic versus geologic fault slip rates in the Eastern California Shear Zone, Geology 31, 55-58.

Duquesnoy, T., E. Barrier, M. Kasser, M. Aurelio, and R. Gaulon (1994). Detection of creep along the Philippine Fault: First results of geodetic measurements on Leyte island, central Philippines, Geophys. Res. Lett. 21, 975-978.

Ergintav, S., R. Bürgmann, S. McClusky, L. Hearn, R. E. Reilinger, H. Meteris, B. Aktuk, O. Gurkan, H. Ozener, R. Cakmak, and N. Yalcin (2002). Postseismic deformation following Izmit earthquake, 17 August 1999, Bull. Seismol. Soc. Am. 92, 194-207.

Fay, N. P., and E. D. Humphreys (2005). Fault slip rates, effects of elastic heterogeneity on geodetic data, and the strength of the lower crust in the Salton Trough region, southern California, J. Geophys. Res. 110, B09401.

Fialko, Y. (2006). Interseismic strain accumulation and the earthquake potential on the southern San Andreas fault system, Nature 441, 968-971.

Findley, W. N., J. S. Lai, and K. Onaran (1976). Creep and Relaxation of Nonlinear Viscoelastic Materials: With an Introduction to Linear Viscoelasticity, Dover Publications, New York, $371 \mathrm{pp}$.

Fletcher, H. J., and J. T. Freymueller (2003). New constraints on the motion of the Fairweather fault, Alaska, from GPS observations, Geophys. Res. Lett. 30, 1139.

Freed, A. M., and R. Bürgmann (2004). Evidence of power-law flow in the Mojave Desert mantle, Nature 430, 548-551.

Freed, A. M., R. Bürgmann, E. Calais, J. Freymueller, and S. Hreinsdóttir (2006). Implications of deformation following the 2002 Denali, Alaska earthquake for postseismic relaxation processes and lithospheric rheology, J. Geophys. Res. 111, B01401.

Fumal, T. E., S. K. Pezzopane, R. J. Weldon, and D. P. Schwartz (1993). A 100-year recurrence interval for the San Andreas fault at Wrightwood, CA, Science 259, 199-203.

Gribb, T., and F. Cooper (1998). Low-frequency shear attenuation in polycrystalline olivine: Grain boundary diffusion and the physical significance of the Andrade model for viscoelasticy, J. Geophys. Res. 103, 27,267-27,279.

Hearn, E. H., R. Bürgmann, and R. E. Reilinger (2002). Dynamics of Izmit earthquake postseismic deformation and loading of the Düzce earthquake hypocenter, Bull. Seismol. Soc. Am. 92, no. 1, 172-193.

Hearn, E. H., S. McClusky, S. Ergintav, and R. E. Reilinger (2009). Izmit earthquake postseismic deformation and dynamics of the North Anatolian Fault Zone, J. Geophys. Res. 114, B08405, doi: 10.1029/ 2008JB006026.

Hearn, E. H., F. F. Pollitz, W. R. Thatcher, and C. T. Onishi (2013). How do "ghost transients" from past earthquakes affect GPS slip rate estimates on southern California faults?, Geochem. Geophys. Geosyst. 14, doi: $10.1002 /$ ggge.20080

Hetland, E. A., and B. H. Hager (2003). Postseismic relaxation across the Central Nevada Seismic Belt, J. Geophys. Res. 108, 2394.

Hetland, E. A., and B. H. Hager (2005). Postseismic and interseismic displacements near a strike-slip fault: A 2D theory for general linear viscoelastic rheologies, J. Geophys. Res. 110, B10401, doi: 10.1029/ 2005JB003689.

Hetland, E. A., and B. H. Hager (2006). Interseismic strain accumulation: Spin-up, cycle invariance, and irregular rupture sequences, Geochem. Geophys. Geosyst. 7, Q05004, doi: 10.1029/2005GC001087. 
Hetland, E. A., M. Simons, and E. M. Dunham (2010). Postseismic and interseismic deformation due to fault creep I: Model description, Geophys. J. Int. 181, 81-98.

Hilley, G. E., R. Bürgmann, P.-Z. Zhang, and P. Molnar (2005). Bayesian inference of plastosphere viscosities near the Kunlun fault, northern Tibet, Geophys. Res. Lett. 32, L01302, doi: 10.1029/ 2004GL021658.

Hubert-Ferrari, A., R. Armijo, G. King, B. Meyer, and A. Barka (2002). Morphology, displacement, and slip rates along the North Anatolian Fault, Turkey, J. Geophys. Res. 107, 2235.

Jackson, I., J. F. Gerald, U. Faul, and B. Tan (2002). Grain-size sensitive seismic wave attenuation in polycrystalline olivine, J. Geophys. Res. 107, 2360.

Johnson, K. M., and P. Segall (2004). Viscoelastic earthquake cycle models with deep stress-driven creep along the San Andreas fault, J. Geophys. Res. 109, B10403, doi: 10.1029/2004JB003096.

Johnson, K. M., R. Bürgmann, and J. T. Freymueller (2009). Coupled after slip and viscoelastic flow following the 2002 Denali Fault, Alaska earthquake, Geophys. J. Int. 176, 670-672.

Kirby, E., N. Harkins, E. Wang, X. Shi, C. Fan, and D. Burbank (2007) Slip rate gradients along the eastern Kunlun fault, Tectonics 26, TC2010.

Klinger, Y., J.-P. Avouac, N. AbouKaraki, L. Dorbath, D. Bourles, and J. L. Reyss (2000). Slip rate on the Dead Sea transform fault in northern Araba valley (Jordan), Geophys. J. Int. 142, 755-768.

Kozaci, O., J. Dolan, R. Finkel, and R. Hartleb (2007). Late Holocene slip rate for the North Anatolian fault, Turkey, from cosmogenic ${ }^{36} \mathrm{Cl}$ geochronology: Implications for the constancy of fault loading and strain release rates, Geology 35, 867-870.

Lacassin, R., F. Valli, N. Arnaud, P. H. Leloup, J. L. Paquette, L. Haibing, P. Tapponnier, M. L. Chevalier, S. Guillot, and G. Maheo (2004). Largescale geometry, offset and kinematic evolution of the Karakorum fault, Tibet, Earth Planet. Sci. Lett. 219, 255-269.

Lasserre, C., P.-H. Morel, Y. Gaudemer, P. Tapponnier, F. Ryerson, G. C. King, F. Metivier, M. Kasser, M. Kashgarian, L. Baichi, L. Taiya, and Y. Daoyang (1999). Postglacial left slip rate and past occurrence of $M \geq 8$ earthquakes on the western Haiyuan fault, Gansu, China, $J$. Geophys. Res. 104, 17,633-17,651.

Le Béon, M., Y. Klinger, A. Q. Amrat, A. Agnon, L. Dorbath, G. Baer, J. C. Ruegg, O. Charade, and O. Mayyas (2008). Slip rate and locking depth from GPS profiles across the southern Dead Sea Transform, J. Geophys. Res. 113, B11403, doi: 10.1029/2007JB005280.

Le Béon, M., Y. Klinger, M. Al-Qaryouti, A.-S. Mériaux, R. C. Finkel, A. Elias, O. Mayyas, F. J. Ryerson, and P. Tapponnier (2010). Early Holocene and Late Pleistocene slip rates of the southern Dead Sea fault determined from ${ }^{10} \mathrm{Be}$ cosmogenic dating of offset alluvial deposits, J. Geophys. Res. 115, B11414, doi: 10.1029/2009JB007198

Le Béon, M., Y. Klinger, A.-S. Mériaux, M. Al-Qaryouti, R. C. Finkel, O. Mayyas, and P. Tapponnier (2012). Quaternary morphotectonic mapping of the Wadi Araba and implications for the tectonic activity of the southern Dead Sea fault, Tectonics 31, TC5003, doi: 10.1029/ 2012TC003112.

Lee, J., J. Spencer, and L. Owen (2001). Holocene slip rates along the Owens Valley fault, California: Implications for the recent evolution of the Eastern California Shear Zone, Geology 29, 819-822.

Li, V. C., and J. R. Rice (1987). Crustal deformation in great California earthquake cycles, J. Geophys, Res. 92, 11,533-11,551.

Lisowski, M., J. C. Savage, and W. H. Prescott (1991). The velocity field along the San Andreas fault in central and southern California, J. Geophys. Res. 96, 8369-8389.

Liu, J., Y. Klinger, K. Sieh, and C. Rubin (2004). Six similar sequential ruptures of the San Andreas faut, Carrizo Plain, California, Geology 32, 649-652.

Liu-Zeng, J., Y. Klinger, K. Sieh, C. Rubin, and G. Seitz (2006). Serial ruptures of the San Andreas Fault, Carrizo Plain, California, revealed by three-dimensional excavations, J. Geophys. Res. 111, B02306, doi: 10.1029/2004JB003601.
Lubetkin, L. K. C., and M. M. Clark (1988). Late Quaternary activity along the Lone Pine fault, eastern California, Bull. Geol. Soc. Am. 100, 755-766.

Marco, S., T. K. Rockwell, A. Heimann, U. Frieslander, and A. Agnon (2005). Late Holocene activity of the Dead Sea Transform revealed in 3D palaeoseismic trenches on the Jordan Gorge segment, Earth Planet. Sci. Lett. 234, 189-205.

Marone, C., C. Scholz, and R. Bilham (1991). On the mechanics of earthquake afterslip, J. Geophys. Res. 96, 8441-8452.

Matmon, A., D. P. Schwartz, R. Finkel, S. Clemmens, and T. Hanks (2005). Dating offset fans along the Mojave section of the San Andreas fault using cosmogenic ${ }^{26} \mathrm{Al}$ and ${ }^{10} \mathrm{Be}$, Bull. Geol. Soc. Am. 117, 795-807.

McGill, S., and K. Sieh (1993). Holocene slip rate of the central Garlock fault in southeastern Searles Valley, California, J. Geophys. Res. 98, $14,217-14,231$

Meade, B. J., and B. H. Hager (2004). Viscoelastic deformation for a clustered earthquake cycle, Geophys. Res. Lett. 31, L10610, doi: 10.1029/2004GL019643.

Meade, B. J., and B. H. Hager (2005). Block models of crustal motion in southern California constrained by GPS measurements, J. Geophys. Res. 110, B03403, doi: 10.1029/2004JB003209.

Meghraoui, M., F. Gomez, R. Sbeinati, J. van der Woerd, M. Mouty, A. N. Darkal, Y. Radwan, I. Layyous, H. Al Najjar, and R. Darawcheh (2003). Evidence for 830 years of seismic quiescence from palaeoseismology, archaeoseismology and historical seismicity along the Dead Sea fault in Syria, Earth Planet. Sci. Lett. 210, 35-52.

Mériaux, A.-S., F. J. Ryerson, P. Tapponnier, J. van der Woerd, R. C. Finkel, X. Xu, Z. Xu, and M. W. Caffee (2004). Rapid slip along the central AltynTagh Fault: Morphochronologic evidence from Cherchen He and Sulamu Tagh, J. Geophys. Res. 109, B06401, doi: 10.1029/ 2003JB002558

Mériaux, A. S., P. Tapponnier, F. J. Ryerson, X. Xiwei, G. King, J. van der Woerd, R. C. Finkel, L. Haibing, M. W. Caffee, X. Zhiqin, and C. Wenbin (2005). The Aksay segment of the northern Altyn Tagh fault: Tectonic geomorphology, landscape evolution, and Holocene slip rate, J. Geophys. Res. 110, B04404, doi: 10.1029/2004JB003210.

Mériaux, A.-S., J. Van der Woerd, P. Tapponnier, F. J. Ryerson, R. C. Finkel, C. Lasserre, and X. Xu (2012). The Pingding segment of the Altyn Tagh Fault $\left(91^{\circ} \mathrm{E}\right)$ : Holocene slip-rate determination from cosmogenic radionuclide dating of offset fluvial terraces, J. Geophys. Res. 117, B09406, 10.1029/2012JB009289.

Merifield, P. M., T. K. Rockwell, and C. C. Loughman (1991). A slip rate based on trenching studies, San Jacinto fault zone near Anza, California, Eng. Geol. Geotech. Eng. 27, 28-1-28-21.

Middleton, T. (2006). Tectonic geomorphology of the southern Clark Fault from Anza southeast to the San Felipe Hills: Implications of slip distribution for recent past earthquakes, M. S. Thesis, San Diego State University.

Miller, M. M., D. J. Johnson, T. H. Dixon, and R. K. Dokka (2001). Refined kinematics of the Eastern California Shear Zone from GPS observations, 1993-1998, J. Geophys. Res. 106, 2245-2263.

Montési, L. G. J. (2004). Controls of shear zone rheology and tectonic loading on postseismic creep, J. Geophys. Res. 109, B10404, doi: 10.1029/ 2003JB002925.

Motagh, M., J. Hoffmann, B. Kampes, M. Baes, and J. Zschau (2007). Strain accumulation across the Gazikoy-Saros segment of the North Anatolian fault inferred from persistent scatterer interferometry and GPS measurements, Earth Planet. Sci. Lett. 255, 432-444.

Niemi, T. M., H. Zhang, H. M. Atallah, and J. B. J. Harrison (2001). Late Pleistocene and Holocene slip rate of the northern Wadi Araba fault, Dead Sea transform, Jordan, J. Seismol. 5, 449-474.

Norris, R. J., and A. F. Cooper (2001). Late Quaternary slip rates and slip partitioning on the Alpine Fault, New Zealand, J. Struct. Geol. 23, 507-520.

Nur, A., and G. Mavko (1974). Postseismic viscoelastic rebound, Science 183, 204-206. 
Petersen, M. D., and S. G. Wesnousky (1994). Fault slip rates and earthquake histories for active faults in southern California, Bull. Seismol. Soc. Am. 84, 1608-1649.

Plafker, G., T. Hudson, T. Bruns, and M. Rubin (1978). Late Quaternary offsets along the Fairweather fault and crustal plate interactions in southern Alaska, Can. J. Earth Sci. 15, 805-816.

Pollitz, F. F. (2003). Transient rheology of the uppermost mantle beneath the Mojave Desert, California, Earth Planet. Sci. Lett. 215, 89-104.

Pollitz, F. F. (2005). Transient rheology of the upper mantle beneath central Alaska inferred from the crustal velocity field following the 2002 Denali earthquake, J. Geophys. Res. 110, B08407, doi: 10.1029/ 2005JB003672.

Pollitz, F. F., C. Wicks, and W. Thatcher (2001). Mantle flow beneath a continental strike-slip fault: Postseismic deformation after the 1999 Hector Mine Earthquake, Science 293, 1814-1818.

Polonia, A., L. Gasperini, A. Amorosi, E. Bonatti, G. Bortoluzzi, N. Cagatay, L. Capotondi, M. H. Cormier, N. Gorur, and C. McHugh (2004). Holocene slip rate of the North Anatolian Fault beneath the Sea of Marmara, Earth Planet. Sci. Lett. 227, 411-426.

Reilinger, R. E., S. Ergintav, R. Burgmann, S. McClusky, O. Lenk, A. Barka, O. Gurkan, L. Hearn, K. L. Feigl, and R. Cakmak (2000). Coseismic and postseismic fault slip for the 17 August 1999, $M=7.5$, Izmit, Turkey earthquake, Science 289, 1519-1524.

Robinson, P. M., and B. J. Meade (2011). Effect of a weak lower crustal channel in Tibet on geodetic velocities (abstract T23B-2393), Eos Trans. AGU, T23B-2393.

Rockwell, T., C. Loughman, and P. Merifield (1990). Late Quaternary rate of slip along the San Jac into fault zone near Anza, southern California, J. Geophys. Res. 95, 8593-8605.

Ryder, I., B. Parsons, T. Wright, and G. J. Funning (2007). Post-seismic motion following the 1997 Manyi (Tibet) earthquake: InSAR observations and modelling, Geophys. J. Int. 169, 1009-1027.

Savage, J. C. (1983). A dislocation model of strain accumulation and release at a subduction zone, J. Geophys. Res. 88, 4984-4996.

Savage, J. C. (1990). Equivalent strike-slip earthquakes cycles in half-space and lithosphere-athenosphere Earth models, J. Geophys. Res. 95, 4873-4879.

Savage, J. C. (2000). Viscoelastic coupling model for the earthquake cycle driven from below, J. Geophys. Res. 105, 25,525-25,532.

Savage, J. C., and R. O. Burford (1973). Geodetic determination of the relative plate motion in central California, J. Geophys. Res. 78, 832-845.

Savage, J. C., and W. H. Prescott (1978). Asthenosphere readjustment and the earthquake cycle, J. Geophys. Res. 83, 3369-3376.

Schmalzle, G., T. Dixon, R. Malservisi, and R. Govers (2006). Strain accumulation across the Carrizo segment of the San Andreas Fault, California: Impact of laterally varying crustal properties, J. Geophys. Res. 111, B05403, doi: 10.1029/2005JB003843.

Segall, P. (2002). Integrating geologic and geodetic estimates of slip rate on the San Andreas fault system, Int. Geol. Rev. 44, 62-82.
Segall, P. (2010). Earthquake and Volcano Deformation, Princeton University Press, 432 pp.

Sharp, R. V. (1967). San Jac into fault zone in the Peninsular Ranges of southern California, Bull. Geol. Soc. Am. 78, 705-730.

Sharp, R. V. (1981). Variable rates of late Quaternary strike slip on the San Jacinto fault zone, southern California, J. Geophys. Res. 86, 1754-1762.

Sieh, K. E., and R. H. Jahns (1984). Holocene activity of the San Andreas fault at Wallace Creek, California, Geol. Soc. Am. Bull. 95, 883-896.

Thatcher, W. (1983). Nonlinear strain buildup and the earthquake cycle on the San Andreas fault, J. Geophys. Res. 88, 5893-5902.

Thatcher, W. (2009). How the continents deform: The evidence from tectonic geodesy, Annu. Rev. Earth Planet. Sci. 37, 237-262.

van der Woerd, J., Y. Klinger, K. Sieh, P. Tapponnier, F. J. Ryerson, and A. S. Meriaux (2006). Long-term slip rate of the southern San Andreas fault from ${ }^{10} \mathrm{Be}-{ }^{26} \mathrm{Al}$ surface exposure dating of an offset alluvial fan, J. Geophys. Res. 111, B04407, doi: 10.1029/2004JB003559.

Vigny, C., P. Huchon, J. C. Ruegg, K. Khanbari, and L. M. Asfaw (2006). Confirmation of Arabia plate slow motion by new GPS data in Yemen, J. Geophys. Res. 111, B02402, doi: 10.1029/2004JB003229.

Wdowinski, S., Y. Bock, G. Baer, L. Prawirodirdjo, N. Bechor, S. Naaman, R. Knafo, Y. Forrai, and Y. Melzer (2004). GPS measurements of current crustal movements along the Dead Sea Fault, J. Geophys. Res. 109, doi: 10.1029/2003JB002640.

Wright, T. J., B. Parsons, P. C. England, and E. J. Fielding (2004). InSAR observations of low slip rates on the major faults of western Tibet, Science 305, 236-239.

Department of Earth \& Planetary Sciences

Harvard University

Cambridge, Massachusetts 02138

meade@fas.harvard.edu

(B.J.M.)

Institut de Physique du Globe de Paris

Sorbonne Paris Cité

Univ Paris Diderot

UMR 7154 CNRS

F-75005 Paris, France

klinger@ipgp.fr

(Y.K.)

Department of Earth and Environmental Sciences

University of Michigan

Ann Arbor, Michigan 48109

ehetland@umich.edu

(E.A.H.)

Manuscript received 7 January 2013 